\title{
CONFLICTS BETWEEN PARENT COMPANY AND NON- CONTROLLING SHAREHOLDERS IN STAKEHOLDER-ORIENTED CORPORATE GOVERNANCE: EVIDENCE FROM JAPAN
}

\author{
Kento FUJITA ${ }^{1}$, Akihiro YAMADA ${ }^{2}$ \\ ${ }^{1}$ Graduate School of Commerce, Chuo University, Tokyo, Japan \\ ${ }^{2}$ Faculty of Commerce, Chuo University, Tokyo, Japan
}

Received 05 February 2021; accepted 06 September 2021

\begin{abstract}
When a company establishes subsidiaries with capital provided by a third party, the subsidiaries' shareholders include the parent company (controlling shareholders) and minority (noncontrolling) shareholders. When shareholders' interests are divergent, conflicts may arise, causing inefficiencies in the management of the subsidiaries or the corporate group. Such conflicts among shareholders are called principal-principal (PP) conflicts. However, adopting stakeholder-oriented corporate governance, a practice prevalent in Japan, may mitigate such PP conflicts. In fact, many Japanese companies report non-controlling interests in their consolidated financial statements. This paper investigates the influence of PP conflicts in Japanese corporate groups. The availability of nonconsolidated and consolidated financial statements in Japan allows for the comparison of parent companies' data with those of the corporate group. The results reveal that (1) the larger the minority shareholders ratio (MER), the more the profits shifted to the parent company, and (2) the larger the MER, the higher the growth of the subsidiaries' sales rates. These results suggest that while the parent company exploits the non-controlling shareholders through profit shifting, it also allocates sales growth opportunities to subsidiaries to mitigate PP conflicts.
\end{abstract}

Keywords: corporate governance, agency theory, principal-principal conflicts, profit shifting, sales growth, Japan.

JEL Classification: M21, M41, G30, G32.

\section{Introduction}

Focusing on a Japanese corporate group, this paper aims to investigate profit shifting to the parent company that can occur due to principal-principal (PP) conflicts between the parent company and the non-controlling shareholders of the subsidiary, and the allocation of sales growth opportunities to the subsidiary to mitigate PP conflicts. In a company where management and ownership are separated, corporate governance is an important mechanism that

${ }^{\star}$ Corresponding author. E-mail: yamada@tamacc.chuo-u.ac.jp

Copyright (c) 2022 The Author(s). Published by Vilnius Gediminas Technical University

This is an Open Access article distributed under the terms of the Creative Commons Attribution License (http://creativecommons. org/licenses/by/4.0/), which permits unrestricted use, distribution, and reproduction in any medium, provided the original author and source are credited. 
influences management decision-making. Furthermore, principal-agent (PA) conflicts can be mitigated through good corporate governance mechanisms (Dharwadkar et al., 2000). However, another type of conflicts arises when there are numerous shareholders and some concentrated shareholding (controlling shareholders). This type of conflicts between controlling and non-controlling shareholders is known as the principal-principal (PP) conflicts (Dharwadkar et al., 2000; Young et al., 2008). Controlling shareholders dominate corporate decision-making and, in many cases, exploit wealth from non-controlling shareholders because they do not receive effective monitoring from other shareholders. This study aims to investigate such PP conflicts.

A potential case of PP conflicts within a corporate group is when a parent company establishes subsidiaries with capital provided by a third party (Almeida \& Wolfenzon, 2006; Bertrand et al., 2002; Faccio et al., 2001; Sakawa \& Watanabel, 2018). In such a case, the shareholders of the subsidiary include the parent company (the controlling shareholder of the subsidiary), which intensively owns the shares of the subsidiary and controls its management, and a small number of non-controlling shareholders. As the parent company can exploit the wealth of the non-controlling shareholders, conflicts between the parent company and the non-controlling shareholders may arise. Previous research has demonstrated that listed subsidiaries controlled by the parent company experience decreased profits (Sakawa \& Watanabel, 2018). However, previous research examining the exploitation of non-controlling shareholders by parent companies has not directly observed profit shifting between parent companies and subsidiaries. In addition, if the dividends of subsidiaries are increased to control the agency costs due to PP conflicts (Bae et al., 2002; Ferris et al., 2003; Gomes, 2000; Lins, 2003), the internal capital of the corporate group decreases, and thus, the growth of the corporate group may be limited (Young et al., 2008). Therefore, to observe the impact of PP conflicts in a corporate group, it is necessary to not only observe the subsidiaries where PP conflicts occur but also analyze the entire corporate group, including the parent company.

Therefore, this paper focuses on Japanese companies to examine profit shifting between parent and subsidiaries and how parent companies mitigate PP conflicts without limiting the growth opportunities of the corporate group. In Japan, non-controlling interests are reported in the consolidated financial statements of many corporate groups. Therefore, PP conflicts within corporate groups may also occur in Japan (Sakawa \& Watanabel, 2018). However, Japanese companies develop strong inter-firm networks (Lincoln \& Gerlach, 2004) and adopt stakeholder-oriented corporate governance, unlike Anglo-American companies (Desender et al., 2016; Yoshimori, 1995). Young et al. (2008) predicted that it may be possible to observe corporate policies that mitigate PP conflicts by studying Japanese firms. In addition, it is mandatory in Japan to publish two sets of financial statements: the non-consolidated financial statements of the parent company and the consolidated financial statements of the corporate group. Therefore, studying Japanese companies will allow comparing the data of the parent company and the corporate group.

Extending the study of Sakawa and Watanabel (2018), this study not only analyzes listed subsidiaries where PP conflicts arise, but also compares parent companies and consolidated corporate groups that include listed subsidiaries. This study presents a robust analysis by comparing exploiting parent companies and groups of companies, including exploited sub- 
sidiaries, and the results are consistent with Sakawa and Watanabel (2018) and support Young et al. (2008)'s prediction. In addition, the nature of corporate governance is generally considered difficult to change because it is strongly influenced by the institutions and practices of different countries (Colpan et al., 2011). In recent years, however, there is a view that non-Anglo-American corporate governance is moving toward an Anglo-American shareholder-oriented corporate governance model under the pressure of the market, especially the US and UK institutional investors (Hansmann \& Kraakman, 2001). This study shows that stakeholder-oriented corporate governance mitigates the influence of PP conflicts better than Anglo-American type corporate governance. This has implications for companies in non-Anglo-American countries in terms of the extent to which they should change their traditional corporate governance and management practices to meet the requirements of their shareholders. In other words, management and policymakers need to consider the benefits of stakeholder-oriented corporate governance that can reduce the impact of PP conflicts, in addition to the costs of changing traditional corporate governance systems and practices. Therefore, this study would be of interest not only to researchers interested in non-AngloAmerican firms, but also to practitioners.

This paper is organized into four sections. Section 1 describes the theoretical and institutional background, and then the hypotheses development process. Section 2 indicates the data analysis methodology. Section 3 presents the main results and provides additional analysis and robustness tests. Finally, Section 4 summarizes the study.

\section{Background and hypotheses development}

\subsection{Stakeholder-oriented corporate governance in Japan}

Corporate governance is characterized by a variety of factors, including the composition of the board of directors, management compensation contracts, ownership structure, and legal system. Therefore, the natural state of corporate governance varies across countries (Colpan et al., 2011). This section focuses on corporate ownership structures and summarizes the Anglo-American type of shareholder-oriented corporate governance and stakeholder-oriented corporate governance in Japan.

First, in Anglo-American countries, the majority of equity is traditionally owned by investors who are widely diversified. In the US, it is rare for a single owner to own more than $10 \%$ of a company's stock; on average, $37.6 \%$ of the equity is owned by individual investors as of 2009 (Lewellyn \& Judge, 2012). As a result, in Anglo-American countries, market control is achieved by individual investors selling their shares in poorly performing companies (Judge \& Zattoni, 2012). In recent years, ownership by institutional investors has increased, and they monitor corporate decision-making as active investors (Charkham \& Ploix, 2005). Thus, corporate governance in Anglo-American countries can be characterized as shareholder-oriented corporate governance based on market mechanisms (Judge \& Zattoni, 2012).

Meanwhile, in Japan, many shares are held inter-corporately. In other words, the equity of Japanese companies is owned by bank-centered or relationship-oriented business groups (Keiretsu) (Aoki, 1990). In a bank-centered ownership structure, the main bank finances the 
company, closely monitors the company's activities, and encourages the company to grow long term (Aguilera \& Jackson, 2003). Under a relationship-oriented ownership structure, by holding shares mutually among industrial companies and offering "mutual hostages" to increase the cost of exit within a business group, the business group builds long-term relationships (Lincoln et al., 1992). In this type of cross-ownership of equity by a business group, the shareholders of the company do not simply demand a financial return; rather in many cases, they are motivated to invest to obtain non-financial strategic benefits such as business trust, information exchange, mutual monitoring, or control (Aguilera \& Jackson, 2003; Clark, 1979; Kester, 1991). Thus, in Japanese companies, equity is owned by banks and industrial corporate groups, and these stakeholders are focused on strategic, long-term inter-company relationships. This requires Japanese companies to formulate and implement strategies based on long-term goals, primarily to maximize market share and growth rather than short-term profits and stock prices (Abegglen \& Stalk, 1985; Blinder, 2000; Desender et al., 2016).

This study focuses on stakeholder-oriented corporate governance in Japan, which is characterized by building of long-term inter-company relationships and expansion of market share, and investigates its relationship with PP conflicts.

\subsection{PP conflicts and stakeholder-oriented corporate governance}

In companies where shares are owned by many shareholders and managed by professional managers, conflicts of interest can arise between shareholders and managers (Jensen \& Meckling, 1976). In general, shareholders are interested in maximizing the market value of their shares, while managers are interested in maximizing their private benefits. Therefore, conflicts of interest between shareholders and managers become significant when managers attempt to maximize their private benefits at the expense of corporate value. Such conflicts between managers and shareholders are called PA conflicts (Jensen \& Meckling, 1976; Shleifer \& Vishny, 1997).

Conflicts of interest between controlling shareholders and minority shareholders, socalled PP conflicts, may arise in companies where shares are concentrated in the hands of certain controlling shareholders (Dharwadkar et al., 2000; Young et al., 2008). Controlling shareholders can dominate corporate decision-making and maximize their private benefits by appointing managers who follow their wishes or by assuming management positions themselves. PP conflicts may arise when controlling shareholders maximize their private benefits by exploiting the wealth of minority shareholders. Scholars have suggested that controlling shareholders maximize private benefits through dividend cuts, excessive cash holdings, tax avoidance, inefficient investments, and related-party transactions (Bauer et al., 2020; Faccio et al., 2001; Huyghebaert \& Wang, 2012; Jebran et al., 2019; Jiang et al., 2015, 2018; OpokuMensah \& Yin, 2021). Additionally, PP conflicts may result in additional agency costs, which may reduce the performance and value of the company (Cronqvist \& Nilsson, 2003; Ferris et al., 2003; Morck et al., 2005; Sauerwald et al., 2019).

PP conflicts may become apparent in corporate groups when the subsidiary has minority shareholders (non-controlling shareholders). Intra-group transactions provide a unique context for the study of potential conflicts within corporate groups because they can be a 
tool for the parent company to exploit the subsidiaries. In fact, several studies have shown that the transfer of resources and benefits occurs within a corporate group (e.g., Almeida \& Wolfenzon, 2006; Chang \& Hong, 2000; Hines \& Rice, 1994; Khanna \& Rivkin, 2001). Previous studies on PP conflicts have found smaller dividend payout ratios and profitability in companies with non-controlling shareholders, suggesting that parent companies exploit the wealth of non-controlling shareholders (Bertrand et al., 2002; Faccio et al., 2001; Sakawa \& Watanabel, 2018).

In addition, because the managers of subsidiaries, appointed by controlling shareholders, can avoid monitoring from non-controlling shareholders (Claessens et al., 2000; La Porta et al., 1999; Shleifer \& Vishny, 1997), the Anglo-American style of shareholderoriented corporate governance is unable to mitigate PP conflicts (Dharwadkar et al., 2000; Young et al., 2008). Stakeholder-oriented corporate governance, however, has the potential to address PP conflicts through monitoring by a network of stakeholders, including shareholders, creditors, employees, and government (Young et al., 2008). In particular, because Japanese companies develop strong inter-company networks in terms of financial, personal, and business relationships, managers of Japanese companies seek to achieve goals that are beneficial to all stakeholders, including non-controlling shareholders (Desender et al., 2016; Lincoln \& Gerlach, 2004; Sakawa \& Watanabel, 2021; Yoshimori, 1995). In fact, Sakawa and Watanabel (2018) focused on the listed subsidiaries in Japan, revealing that the sales growth rate is greater in listed subsidiaries with strong parent company control; this finding suggested that PP conflicts are less likely to surface in Japan.

\subsection{Institutional background}

Listed (parent) companies in Japan are required to disclose both non-consolidated and consolidated financial statements. Consolidated financial statements are prepared by aggregating the non-consolidated financial statements of the parent company and its consolidated subsidiaries and eliminating internal transactions (Accounting Standards Board of Japan [ASBJ], 2013, paras. 1, 31,35). The consolidated subsidiaries mainly include companies in which the parent company holds more than $50 \%$ of the voting rights, or companies in which the parent company holds between $40 \%$ and $50 \%$ of the voting rights and controls the decision-making bodies, such as shareholders' meetings and the board of directors (ASBJ, 2013, paras. 5, 6, 13,54). Minority shareholders in subsidiaries are called non-controlling shareholders, and the portion of the subsidiary's net assets owned by non-controlling shareholders is reported as non-controlling interests in the consolidated balance sheet.

Table 1 summarizes the status of non-controlling interests in Japanese companies. From 2009 to 2018, the mean percentage of companies listed on the first section of the Tokyo Stock Exchange in Japan (the analysis sample of this study) with non-controlling interests was $71.5 \%$. One factor in the presence of non-controlling shareholders in many Japanese corporate groups is the Japanese practice of listing subsidiaries. In Japan, a stock market for small and medium-sized companies was created in the 2000s, allowing many subsidiaries to be listed (Sakawa \& Watanabel, 2012). Although the number of non-controlling share- 
holders increases with the listing of a subsidiary, decision-making in listed subsidiaries is generally controlled by the parent company (Financial Times, 2007a, 2007b). However, as seen in Table 1, while the mean number of subsidiaries of Japanese companies is 28.410, the mean of the number of listed subsidiaries is 0.126 , and the ratio of listed subsidiaries to subsidiaries is only $0.442 \%$. Another important factor that can give rise to non-controlling shareholders is the establishment of foreign subsidiaries. When a Japanese company expands to foreign countries, it sometimes establishes a subsidiary through joint investment with a partner company in that country, and such a partner company is treated as a noncontrolling shareholder in the consolidated financial statements. For example, when Japanese companies enter China, they often take the form of joint ventures with local Chinese companies or other Japanese companies (Pan, 1997; Pan \& Li, 2000). Therefore, the study on PP conflicts for listed subsidiaries covers only a small portion of the entities where PP conflicts can occur. To clarify how PP conflicts within a corporate group are related to the management of the entire corporate group, it is necessary to analyze the entire corporate group, including unlisted subsidiaries.

Table 1. The status of non-controlling interests in Japan

\begin{tabular}{|c|c|c|c|c|}
\hline $\mathrm{N}$ & $\begin{array}{c}\text { SUB } \\
\text { Mean }\end{array}$ & $\begin{array}{c}\text { LISTSUB } \\
\text { Mean }\end{array}$ & LISTSUB Ratio & $\begin{array}{c}\text { Firm groups with } \\
\text { minority } \\
\text { shareholders }\end{array}$ \\
\hline 10315 & 28.410 & 0.126 & $0.442 \%$ & $71.500 \%$ \\
\hline
\end{tabular}

Note: "SUB Mean" is the mean of the number of subsidiaries owned by the parent company; "LISTSUB Mean" is the mean of the number of listed subsidiaries owned by the parent company; "LISTSUB Ratio" is the ratio of LISTSUB Mean to SUB Mean; "Firm groups with minority shareholders" indicates the percentage of corporate groups with minority shareholders.

\subsection{Hypotheses development}

PP conflicts within a corporate group can occur when a parent company accepts capital contributions from a third party to establish its subsidiaries (Almeida \& Wolfenzon, 2006; Bertrand et al., 2002; Faccio et al., 2001; Sakawa \& Watanabel, 2018). The parent company is not effectively monitored by other shareholders and may, therefore, exploit the wealth of minority shareholders. In fact, even in Japan, reduced profitability has been observed in listed subsidiaries with non-controlling shareholders (Sakawa \& Watanabel, 2018).

When observing PP conflicts between the parent company and non-controlling shareholders in a corporate group, it is useful to note that the financial statements of both the parent company and the corporate group can be observed simultaneously. However, many previous studies have focused only on the companies with PP conflicts. In contrast, if the financial statements of the parent company and the corporate group can be compared, it is possible to observe the shift of profits to the parent company from the exploiting parent company and from the corporate group, including the exploited subsidiaries.

If profits are shifted from the subsidiaries to the parent company for the purpose of exploiting the wealth of the non-controlling shareholders, then the net income of the parent company's non-consolidated financial statements would increase as non-controlling 
interests in the subsidiaries increase. The net income in the consolidated financial statements would not increase because profits from internal transactions are offset. Therefore, the following hypothesis was proposed:

Hypothesis 1: In the parent company's non-consolidated financial statements, the higher the percentage of non-controlling interests, the larger is the net income.

PP conflicts may be mitigated by stakeholder-oriented corporate governance in Japanese companies (Young et al., 2008). Japanese companies are characterized by their desire to maximize market share and sales (Abegglen \& Stalk, 1985; Blinder, 2000; Desender et al., 2016). If sales growth opportunities are allocated to subsidiaries with PP conflicts between the parent company and the non-controlling shareholders, then wealth is distributed to all shareholders of the subsidiaries, including the non-controlling shareholders, which allows the entire corporate group to grow while limiting the increase in agency costs associated with PP conflicts. In this regard, Sakawa and Watanabel (2018) determined that for listed subsidiaries of Japanese companies, when control by the parent company is relatively stronger, the growth in sales of the subsidiary is higher.

As stated in Hypothesis 1, this paper examines PP conflicts between the parent company and non-controlling shareholders and the allocation of sales growth opportunities within the corporate group by comparing non-consolidated and consolidated financial statements. If the parent company allocates sales growth opportunities to the subsidiary to mitigate PP conflicts in the subsidiary, then with larger non-controlling interests, higher sales growth should be observed in the consolidated financial statements of the corporate group, not in the non-consolidated financial statements of the parent company. Therefore, another hypothesis was proposed as follows:

Hypothesis 2: In the consolidated financial statements of a corporate group, the higher the percentage of non-controlling interests, the higher is the growth in sales.

\section{Sample and methods}

\subsection{Estimation models for testing profit shifting}

To observe profit shifting from the subsidiaries to the parent company, this study applies the model of Hines and Rice (1994). They presented the theoretical and estimation models that analyzed the profits shifting within a corporate group to reduce the taxes and maximize the wealth distributed to shareholders. This study relies on their model to observe profit shifting from non-controlling shareholders to the parent company for the purpose of wealth exploitation. The following models are estimated using non-consolidated and consolidated financial statements, and the estimation results are compared to distinguish between purely parent company profit increases and profit shifting within a corporate group. The estimation equations are given below and are estimated by the ordinary least squares (OLS) method.

$$
\begin{aligned}
\ln N I_{-} s_{i, t}= & \alpha_{0}+\alpha_{1} M E R_{-} c_{i, t}+\alpha_{2} \ln L_{-} s_{i, t}+\alpha_{3} \ln K_{-} s_{i, t} \\
& +\alpha_{4} \ln R D I N T_{-} s_{i, t}+\alpha_{5} \ln L I S T S U B R_{-} c_{i, t}+\alpha_{6} D H O L D I N G S_{-} s_{i, t} \\
& +\alpha_{7} D_{N} D_{i, t}+\alpha_{8} D Y E A R_{i, t}+\varepsilon ;
\end{aligned}
$$




$$
\begin{aligned}
\ln N \__{-} c_{i, t}= & \beta_{0}+\beta_{1} M E R \_c_{i, t}+\beta_{2} \ln L_{-} c_{i, t}+\beta_{3} \ln K_{-} c_{i, t} \\
& +\beta_{4} \ln R D I N T_{-} c_{i, t}+\beta_{5} \ln \text { LISTSUBR_c } c_{i, t}+\beta_{6} \text { DHOLDINGS_s } s_{i, t} \\
& +\beta_{7} \text { DIND }_{i, t}+\beta_{8} D Y E A R_{i, t}+\varepsilon .
\end{aligned}
$$

The _s in each variable represents that the variables are created from non-consolidated (separate) financial statements, and the _c represents that the variables are created from consolidated financial statements. In addition, $i$ and $t$ in the subscript of each variable represent the company and year, respectively.

The dependent variable in Eq. (1), NI_s, is the net income of the parent company. The independent variable MER_c is the ratio of non-controlling interests to net assets (minority equity ratio). According to Hypothesis 1 , the coefficient $\left(\alpha_{1}\right)$ of MER_c is expected to be positive. Eq. (2) was used for comparison with Eq. (1). The profit shifting from the subsidiaries to the parent company does not affect the net income in the consolidated financial statements (NI_c) because it is an internal transaction of the corporate group. Therefore, as shown in Hypothesis 1, if there is profit shifting from the subsidiaries to the parent company, then $\alpha_{1}$ in Eq. (1) is estimated to be positive, while $\beta_{1}$ in Eq. (2) is not expected to be statistically significant.

The other independent variables included in Eqs. (1) and (2) proxy each element of the Cobb-Douglas type function for estimating expected profits. $L$ is the sum of the number of employees and the average number of temporary employees at the end of the period, and $\mathrm{K}$ is the property, plant, and equipment at the end of the period, representing labor input and capital input, respectively. RDINT, LISTSUBR, and DHOLDINGS are variables that control for productivity shifts and profitability shifts due to innovation and firm structure. RDINT is R\&D intensity and controls for productivity shifts due to innovation (Griliches, 1988). LISTSUBR is the ratio of listed subsidiaries to total subsidiaries, and DHOLDINGS is a dummy variable that takes the value 1 if the corporate group adopts a holding company system and 0 otherwise. These are used to control for the effect of corporate group structure on profitability. DIND and DYEAR are industry and year dummies, respectively. Note that NI, L, K, RDINT, and LISTSUBR are converted to natural logarithms, according to Hines and Rice (1994) (Appendix).

\subsection{Estimation models for testing sales growth allocations}

To observe the allocation of sales growth opportunities to mitigate PP conflicts, Eqs (3) and (4) are estimated by OLS.

$$
\begin{aligned}
G S_{-} s_{i, t}= & \gamma_{0}+\gamma_{1} M E R_{-} c_{i, t}+\gamma_{2} \text { TOP } 10_{-} s_{i, t}+\gamma_{3} E X E C_{-} s_{i, t}+\gamma_{4} F I N_{-} s_{i, t} \\
& +\gamma_{5} F G N_{-} s_{i, t}+\gamma_{6} \text { BIG4_c } c_{i, t}+\gamma_{7} Q_{-} s_{i, t}+\gamma_{8} S I Z E_{-} s_{i, t} \\
& +\gamma_{9} R I S K_{-} s_{i, t}+\gamma_{10} \text { CAPITAL_s } s_{i, t}+\gamma_{11} A G E_{-} s_{i, t} \\
& +\gamma_{12} D I N D_{i, t}+\gamma_{13} D Y E A R_{i, t}+\varepsilon ;
\end{aligned}
$$




$$
\begin{aligned}
G S_{-} c_{i, t}= & \zeta_{0}+\zeta_{1} M E R_{-} c_{i, t}+\zeta_{2} T O P 10_{-} s_{i, t}+\zeta_{3} E X E C_{-} s_{i, t}+\zeta_{4} F I N_{-} s_{i, t} \\
& +\zeta_{5} F G N_{-} s_{i, t}+\zeta_{6} B I G 4_{-} c_{i, t}+\zeta_{7} Q_{-} c_{i, t}+\zeta_{8} S I Z E_{-} c_{i, t} \\
& +\zeta_{9} R I S K_{-} s_{i, t}+\zeta_{10} \text { CAPITAL_c } c_{i, t}+\zeta_{11} A G E_{-} s_{i, t} \\
& +\zeta_{12} D I N D_{i, t}+\zeta_{13} D Y E A R_{i, t}+\varepsilon .
\end{aligned}
$$

The _s in each variable represents that the variables are created from non-consolidated (separate) financial statements, and the _c represents that the variables are created from consolidated financial statements. In addition, $i$ and $t$ in the subscript of each variable represent the company and year, respectively.

First, GS_c, the dependent variable in Eq. (4), represents the growth of sales of the entire corporate group. The independent variable, MER_c, represents the ratio of noncontrolling interests to net assets in the consolidated financial statements, as in Eqs (1) and (2). According to Hypothesis 2, the coefficient of MER_c, $\zeta_{1}$, is expected to be positive. Eq. (3) was used for comparison with Eq. (4). If the parent company allocates sales growth opportunities to its subsidiaries to mitigate PP conflicts in its subsidiaries, then the relationship between the parent company's sales growth (GS_s) and MER_c should not be observed as pronounced as the relationship between GS_c and MER_c.

Other independent variables represent firm characteristics related to the parent company's shareholder structure, auditing, and expected growth rate (Sakawa \& Watanabel, 2018, 2020). TOP10_s, EXEC_s, FIN_s, FGN_s, and BIG4_c are used to control for corporate governance status. TOP10_s is the top 10 shareholders', EXEC_s is the executives', FIN_s is the financial institutions', and FGN_s is the foreign investors' shareholding ratio of the parent company's shares. BIG4_c is a dummy variable that is set to 1 if the consolidated financial statements are audited by one of the Big 4 audit firms and 0 otherwise. Q, SIZE, RISK, CAPITAL, and AGE were used to control the expected growth rate. Q is Tobin's q, SIZE is the natural logarithm of total assets, RISK is the volatility of stock returns, CAPITAL is net assets as a percentage of total assets, AGE_s is the corporate age of the parent company, and DIND and DYEAR are industry and year dummies, respectively (Appendix).

\subsection{Sample selection}

The financial and stock data for the analysis were obtained from Nikkei NEEDs Financial Quest by Nikkei Media Marketing, Inc. Additionally, the auditor data were obtained from eol database by Pronexus Inc. The sample selection criteria are as follows:

- The period is from 2008 to 2019.

- The company is listed on the first section of the Tokyo Stock Exchange.

- The company is a general business company (non-financial industry).

- The fiscal period is 12 months.

- The company can obtain both non-consolidated and consolidated financial statements.

Of the observations satisfying the above conditions, there were 12,179 firm-years of observations with no missing values in the data necessary to create the variables. Finally, observations that were more than three standard deviations from the mean for each variable were excluded as outliers. As a result, the observed value was 10,315 firm-years. Table 2 shows the descriptive statistics of each variable. 
Table 2. Descriptive statistics ( $\mathrm{N}=10,315$ observations)

\begin{tabular}{|l|c|c|c|c|c|}
\hline \multicolumn{1}{|c|}{ Variable } & Mean & Median & Min & Max & S.D. \\
\hline lnNI_s & 7.816 & 7.745 & 3.136 & 12.470 & 1.464 \\
\hline lnNI_c & 8.139 & 8.052 & 3.434 & 12.984 & 1.498 \\
\hline GS_s & 0.021 & 0.022 & -1.000 & 1.816 & 0.160 \\
\hline GS_c & 0.035 & 0.032 & -0.368 & 0.456 & 0.096 \\
\hline MER_c & 0.025 & 0.007 & -0.033 & 0.198 & 0.038 \\
\hline lnL_s & 6.841 & 6.842 & 2.303 & 10.868 & 1.378 \\
\hline lnL_c & 8.005 & 7.931 & 3.664 & 12.374 & 1.363 \\
\hline lnK_s & 9.506 & 9.567 & 2.996 & 15.514 & 1.847 \\
\hline lnK_c & 10.131 & 10.074 & 4.331 & 15.591 & 1.757 \\
\hline lnRDINT_s & 0.013 & 0.000 & 0.000 & 0.114 & 0.023 \\
\hline lnRDINT_c & 0.014 & 0.005 & 0.000 & 0.104 & 0.020 \\
\hline lnLISTSUBR_c & 0.002 & 0.000 & 0.000 & 0.076 & 0.009 \\
\hline DHOLDINGS_s & 0.042 & 0.000 & 0.000 & 1.000 & 0.201 \\
\hline TOP10_s & 0.447 & 0.424 & 0.124 & 0.874 & 0.137 \\
\hline EXEC_s & 0.038 & 0.006 & 0.000 & 2.420 & 0.083 \\
\hline FIN_s & 0.262 & 0.254 & 0.022 & 0.607 & 0.115 \\
\hline FGN_s & 0.148 & 0.124 & 0.001 & 0.529 & 0.113 \\
\hline BIG4_c & 0.816 & 1.000 & 0.000 & 1.000 & 0.387 \\
\hline Q_s & 1.262 & 1.083 & 0.345 & 4.672 & 0.592 \\
\hline Q_c & 1.107 & 0.986 & 0.344 & 3.810 & 0.435 \\
\hline SIZE_s & 11.387 & 11.215 & 7.316 & 15.704 & 1.337 \\
\hline SIZE_c & 11.613 & 11.428 & 7.670 & 15.975 & 1.392 \\
\hline RISK_s & 0.336 & 0.249 & 0.000 & 3.103 & 0.342 \\
\hline CAPITAL_s & 0.547 & 0.551 & -0.021 & 0.998 & 0.197 \\
\hline CAPITAL_c & 0.526 & 0.530 & -0.019 & 0.962 & 0.186 \\
\hline AGE_s & 61.770 & 64.000 & 3.000 & 135.000 & 24.023 \\
\hline
\end{tabular}

\section{Results}

\subsection{Main results}

Table 3 summarizes the main results. First, for Model 1, in which the lnNI_s of non-consolidated financial statements is the dependent variable, the coefficient of MER_c is 2.568, which is statistically significant at the $1 \%$ level. For Model 2, where lnNI_c of consolidated financial statements is the dependent variable, the coefficient of MER_c is not statistically significant. These results are consistent with Hypothesis 1 and suggest that the higher the non-controlling interest, the more profits are shifted from the subsidiary to the parent, and the more serious is the PP conflicts in the subsidiary. These results are consistent with the prediction of Young et al. (2008) that PP conflicts will lead to the exploitation of non-controlling shareholders' 
wealth. It is also consistent with the work of Sakawa and Watanabel (2018), who analyzed Japanese listed subsidiaries. In particular, the fact that the relationship between net income and MER observed in the non-consolidated financial statements is not observed in the consolidated financial statements indicates that the increase in net income of the parent company is caused by internal transactions within the corporate group. Another interesting finding is that PP conflicts were observed in the setting of the ownership structure of a corporate group, that is, the parent company and the non-controlling shareholders of its subsidiaries, rather than simply between shareholders. As Young et al. (2008) point out, PP conflicts can have a negative impact on a company's performance and competitiveness, or on its cost of capital. The impact of PP conflicts needs to be mitigated under Japan's stakeholder-oriented corporate governance, where the parent company, as the controlling shareholder, is monitored by many stakeholders, including banks and other companies.

For the control variables, the coefficients for each variable show results consistent with expectations, and the estimated model based on Hines and Rice (1994) is reasonable for the data in this study. The coefficients of $\ln L \_s\left(\operatorname{lnL} c\right.$ c), $\ln K \_s\left(\operatorname{lnK} \_c\right)$, and $\ln R D I N T \_s$ (lnRDINT_c) in Model 1 (Model 2) are estimated to be positive, and all are statistically significant at the $5 \%$ level or higher. This indicates that the greater the labor or capital input, or the more intensive the R\&D, the higher the profits. Also, lnLISTSUBR_c and DHOLDINGS_s are statistically significant at the $1 \%$ level only for Model 1 . Thus, when the percentage of listed subsidiaries is high, or when a corporate group adopts a holding company structure, the profits of the parent company tend to be higher, even after controlling for other factors.

For Model 3, which uses GS_s of non-consolidated financial statements as the dependent variable, the coefficient of MER_c is not statistically significant. For Model 4, where GS_c in the consolidated financial statements is the dependent variable, the coefficient of MER_c is 0.095 and statistically significant at the $1 \%$ level. These results are consistent with Hypothesis 2, suggesting that the larger the non-controlling interest, the more the parent company allocates sales growth opportunities to its subsidiaries, thereby mitigating the effects of PP conflicts. In particular, the fact that the increase in sales growth observed in the consolidated financial statements is not observed in the parent company's non-consolidated financial statements suggests that the parent company is actively allocating sales growth opportunities to its subsidiaries with non-controlling shareholders rather than to the parent company itself. As shown in the results of Hypothesis 1, the larger the non-controlling interest, the more likely profit is shifted from the subsidiaries to the parent company, and the more likely the influence of PP conflicts becomes serious. However, a parent company under a stakeholder-oriented corporate governance system, such as that of Japanese companies, may address PP conflicts by allocating sales growth opportunities to subsidiaries with non-controlling shareholders, without limiting the growth opportunities of the corporate group.

For the control variables, the coefficients for each variable show results consistent with Sakawa and Watanabel $(2018,2020)$. TOP10_s, EXEC_s, FIN_s, and FGN_s of corporate ownership are related to the sales growth of the entire corporate group. On the other hand, firm growth potential (Q), risk (RISK), and firm age (AGE) affect the sales growth of both the parent company and the corporate group. 


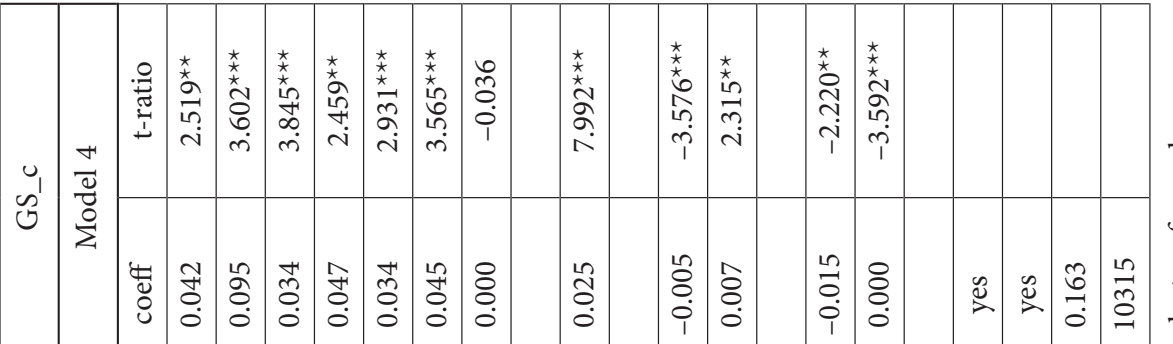

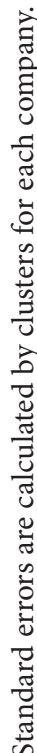

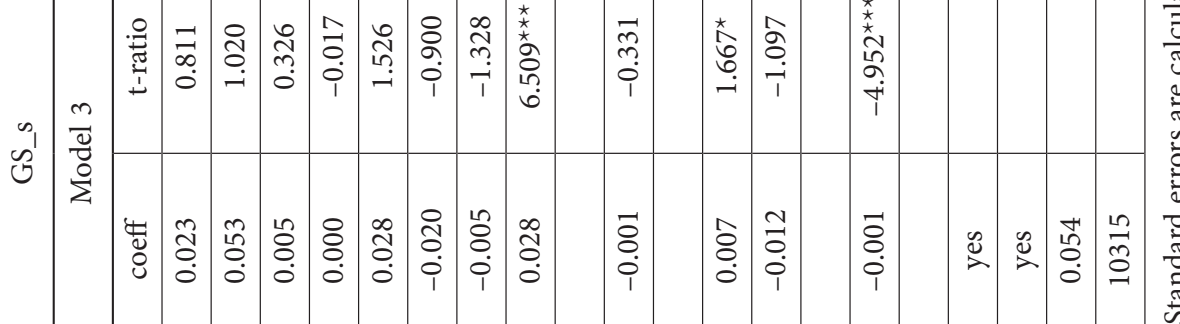

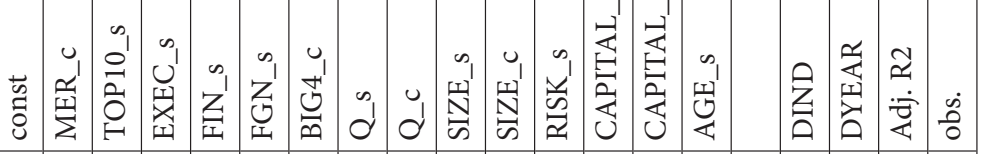

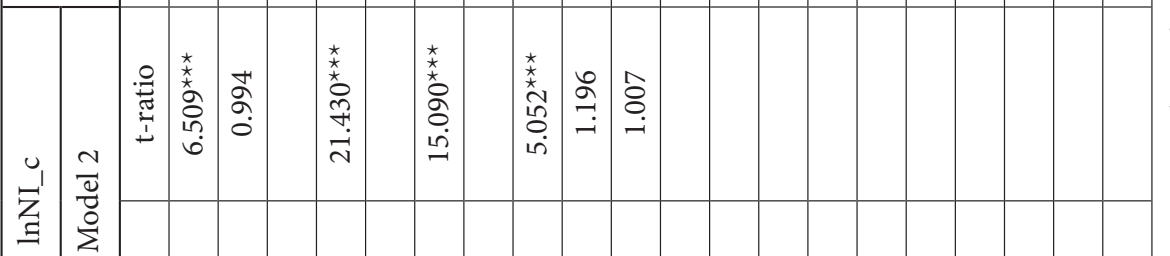

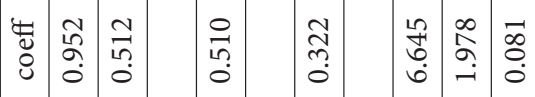

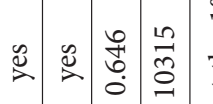

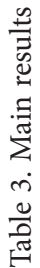

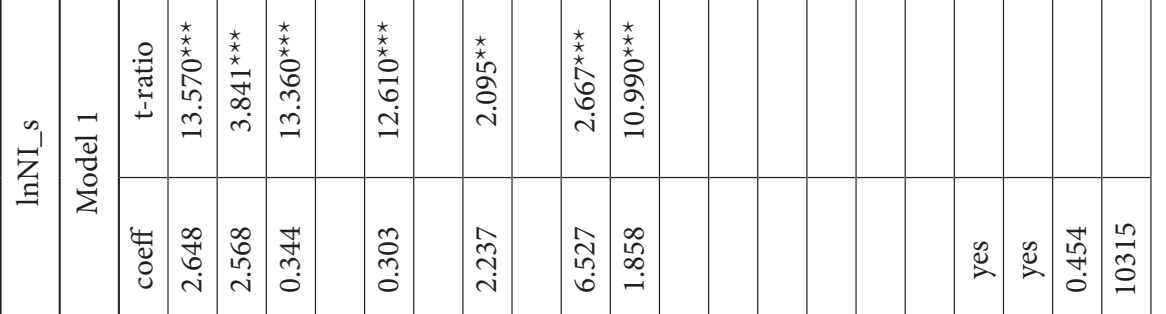

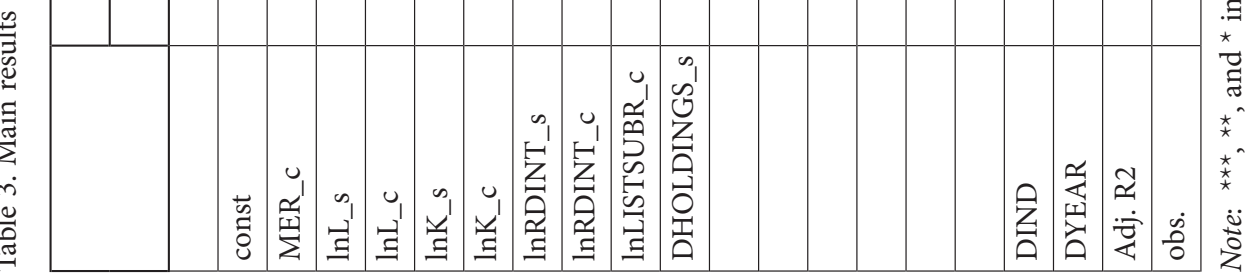


In sum, these results are consistent with those of previous studies such as Bertrand et al. (2002), Faccio et al. (2001), and Sakawa and Watanabel (2018). This study analyzes both the exploiting parent company and the corporate group that includes the exploited subsidiary. Thus, compared to previous studies, this study provides robust evidence on exploitation caused by PP conflicts and mitigation of PP conflicts through the distribution of sales growth opportunities.

\subsection{Additional tests}

\subsubsection{Effect of parent company's foreign shareholding ratio}

This study focuses on Japanese companies because many Japanese companies may adopt stakeholder-oriented corporate governance (Desender et al., 2016). However, it is possible that not all Japanese companies engage in stakeholder-oriented corporate governance. Bank restructuring due to the recession of the Japanese economy led to the elimination of some cross-shareholdings and increased the influence of foreign investors (Desender et al., 2016). Approximately $60 \%$ of foreign investors in Japanese companies are from the US and UK (Bank of Japan, 1996-2012), and they may demand shareholder-oriented corporate governance. ${ }^{1}$ Therefore, proportion of foreign ownership is categorized into three subsamples and their estimation results are observed independently. Table 4 shows the descriptive statistics for each subsample.

Table 4. Descriptive statistics of the subsamples

\begin{tabular}{|l|c|c|c|c|c|c|}
\hline \multirow{3}{*}{} & \multicolumn{5}{|c|}{ Foreign Ownership } \\
\cline { 2 - 7 } & \multicolumn{2}{|c|}{ Low $(\mathrm{N}=3435)$} & \multicolumn{2}{c|}{ Middle $(\mathrm{N}=3435)$} & \multicolumn{2}{c|}{ High $(\mathrm{N}=3445)$} \\
\cline { 2 - 7 } & Mean & S.D. & Mean & S.D. & Mean & S.D. \\
\hline FGN_s & 0.036 & 0.020 & 0.124 & 0.031 & 0.282 & 0.077 \\
\hline MER_c & 0.017 & 0.032 & 0.025 & 0.038 & 0.032 & 0.041 \\
\hline
\end{tabular}

Table 5 summarizes the results of profit shifting between parent and subsidiary companies. The models for Panel A in Table 5 use lnNI_s as the dependent variable. In Model 5, the subsample with the lowest percentage of foreign ownership, the coefficient of MER_c is positive and statistically significant at the $10 \%$ level. Furthermore, in Model 7 , the subsample with the highest foreign ownership ratio, the coefficient of MER_c is positive and statistically significant at the $5 \%$ level. These results indicate that for parent companies with low and high foreign ownership, the higher the non-controlling interest in the subsidiary, the higher is the profit. To check whether the estimation results of Panel A in Table 5 imply exploitation by the parent company, refer to Panel B in Table 5, which uses lnNI_c as the dependent variable. In Model 8, which estimates the smallest subsample of foreign ownership, the coefficient of MER_c is positive and statistically significant at the 5\% level. Interpreting the results of both

\footnotetext{
1 Since 2010, the number of Chinese investors has also been increasing: in 2012, Chinese investors accounted for about 13\% of foreign investors in Japanese companies (Bank of Japan, 1996-2012). China's corporate governance system is characterized by a strong influence of the Chinese government's intentions (He et al., 2013).
} 
Model 5 and Model 8, the relationship between non-controlling interests and profits in the parent company with a small foreign shareholding cannot be interpreted as being due to profit shifting from the subsidiaries. The coefficient of MER_c is not statistically significant in Model 10, which estimates the subsample with the largest percentage of foreign ownership. Based on the results of Models 7 and 10, the relationship between non-controlling interests and profits generated in a parent company with a large percentage of foreign ownership is interpreted as an income increase due to the profit shifting from the subsidiaries to the parent company.

Table 5. Foreign ownership and profit shifting

\begin{tabular}{|c|c|c|c|c|c|c|}
\hline & \multicolumn{6}{|c|}{ Foreign Ownership } \\
\hline & \multicolumn{2}{|c|}{ Low $(\mathrm{N}=3435)$} & \multicolumn{2}{|c|}{ Middle $(\mathrm{N}=3435)$} & \multicolumn{2}{|c|}{$\operatorname{High}(\mathrm{N}=3445)$} \\
\hline \multicolumn{7}{|c|}{ Panel A: Dependent variable: lnNI_s } \\
\hline & \multicolumn{2}{|c|}{ Model 5} & \multicolumn{2}{|c|}{ Model 6} & \multicolumn{2}{|c|}{ Model 7} \\
\hline & coeff & t-ratio & coeff & t-ratio & coeff & t-ratio \\
\hline const & 3.825 & $16.050^{* * *}$ & 4.730 & $21.320^{* * *}$ & 3.723 & $13.030^{* * *}$ \\
\hline MER_c & 1.536 & $1.648^{*}$ & 0.989 & 1.351 & 2.122 & $2.259^{\star *}$ \\
\hline $\operatorname{lnL} \_s$ & 0.219 & $7.029^{\star * *}$ & 0.199 & $6.597^{\star * *}$ & 0.302 & $7.471^{\star * *}$ \\
\hline $\ln \mathrm{l} \_s$ & 0.174 & $6.755^{\star * *}$ & 0.200 & $7.221^{\star * *}$ & 0.282 & $8.123^{* * *}$ \\
\hline Controls & yes & & yes & & yes & \\
\hline DIND & yes & & yes & & yes & \\
\hline DYEAR & yes & & yes & & yes & \\
\hline Adj. R2 & 0.245 & & 0.357 & & 0.428 & \\
\hline \multicolumn{7}{|c|}{ Panel B: Dependent variable: lnNI_c } \\
\hline & \multicolumn{2}{|c|}{ Model 8} & \multicolumn{2}{|c|}{ Model 9} & \multicolumn{2}{|c|}{ Model 10} \\
\hline & coeff & t-ratio & coeff & t-ratio & coeff & t-ratio \\
\hline const & 2.953 & $13.240^{* * *}$ & 3.265 & $16.150^{\star * *}$ & 1.744 & $7.533^{* * *}$ \\
\hline MER_c & 1.826 & $2.540^{* *}$ & 0.371 & 0.559 & 0.630 & 0.946 \\
\hline $\operatorname{lnL} \_c$ & 0.272 & $7.456^{* * *}$ & 0.333 & $11.050^{* * *}$ & 0.420 & $11.670^{* * *}$ \\
\hline $\ln K_{-} c$ & 0.226 & $8.532^{\star * *}$ & 0.237 & $9.173^{\star * *}$ & 0.368 & $10.650^{* * *}$ \\
\hline Controls & yes & & yes & & yes & \\
\hline DIND & yes & & yes & & yes & \\
\hline DYEAR & yes & & yes & & yes & \\
\hline Adj. R2 & 0.351 & & 0.514 & & 0.665 & \\
\hline
\end{tabular}

Note: ${ }^{* * *},{ }^{* *}$, and ${ }^{*}$ indicate statistically significant at the $1 \%, 5 \%$, and $10 \%$ levels, respectively. Standard errors are calculated by clusters for each company. 
Table 6 summarizes the results on the allocation of sales growth opportunities in the corporate group. Panel A of Table 6 uses GS_s as the dependent variable. The coefficient of MER_c for Model 11, the subsample with the lowest foreign ownership ratio, is 0.114 and statistically significant at the $10 \%$ level, yet no statistically significant coefficient is observed for the subsamples with the middle and highest foreign ownership ratios. In contrast, the results of Panel B in Table 6, where GS_c is the dependent variable, reveal that the coefficients of MER_c for Model 14 and Model 15 are 0.149 and 0.109, respectively, which are statistically significant at the $5 \%$ level or higher. These results suggest that in the subsamples with the lowest and middle foreign shareholding ratios, which are considered to be more stakeholder-oriented, sales growth is more pronounced in the corporate group than in the parent company, and sales growth opportunities are allocated to subsidiaries.

Table 6. Foreign ownership and growth of sales

\begin{tabular}{|c|c|c|c|c|c|c|}
\hline & \multicolumn{6}{|c|}{ Foreign Ownership } \\
\hline & \multicolumn{2}{|c|}{ Low $(\mathrm{N}=3435)$} & \multicolumn{2}{|c|}{ Middle $(\mathrm{N}=3435)$} & \multicolumn{2}{|c|}{$\operatorname{High}(\mathrm{N}=3445)$} \\
\hline \multicolumn{7}{|c|}{ Panel A: Dependent variable: GS_s } \\
\hline & \multicolumn{2}{|c|}{ Model 11} & \multicolumn{2}{|c|}{ Model 12} & \multicolumn{2}{|c|}{ Model 13} \\
\hline & coeff & t-ratio & coeff & t-ratio & coeff & t-ratio \\
\hline const & 0.052 & 1.213 & 0.067 & 1.042 & 0.011 & 0.208 \\
\hline MER_c & 0.114 & $1.781^{\star}$ & 0.098 & 1.036 & -0.050 & -0.470 \\
\hline Controls & yes & & yes & & yes & \\
\hline DIND & yes & & yes & & yes & \\
\hline DYEAR & yes & & yes & & yes & \\
\hline Adj. R2 & 0.064 & & 0.043 & & 0.054 & \\
\hline \multicolumn{7}{|c|}{ Panel B: Dependent variable: GS_c } \\
\hline & \multicolumn{2}{|c|}{ Model 14} & \multicolumn{2}{|c|}{ Model 15} & \multicolumn{2}{|c|}{ Model 16} \\
\hline & coeff & t-ratio & coeff & t-ratio & coeff & t-ratio \\
\hline const & 0.049 & 1.498 & 0.098 & $2.987^{\star * *}$ & 0.015 & 0.535 \\
\hline MER_c & 0.149 & $2.836^{* * *}$ & 0.109 & $2.299^{\star *}$ & 0.051 & 1.162 \\
\hline Controls & yes & & yes & & yes & \\
\hline DIND & yes & & yes & & yes & \\
\hline DYEAR & yes & & yes & & yes & \\
\hline Adj. R2 & 0.148 & & 0.157 & & 0.190 & \\
\hline
\end{tabular}

Note: ${ }^{* * *},{ }^{* *}$, and ${ }^{*}$ indicate statistically significant at the $1 \%, 5 \%$, and $10 \%$ levels, respectively. Standard errors are calculated by clusters for each company. 


\subsubsection{MER and internal transactions}

The estimation model of profit shifting is in accordance with Hines and Rice (1994). However, the choice of model may affect the estimation results. Therefore, this section re-examines profit shifting by observing the volume of internal transactions in corporate groups. If the profits of the subsidiary are shifted to the parent company, the higher the non-controlling interest in the subsidiaries, the larger is the volume of internal transactions.

This section estimates Tobit models with the volume of goods transactions within the corporate group (INTTRADE) or the volume of financial transactions (INTFIN) as the dependent variables and MER_c as the independent variable. INTTRADE is the sum of sales and purchases from internal transactions within the corporate group divided by the total sales of the corporate group. INTFIN is the sum of interest and dividend income from internal transactions divided by the total sales of the corporate group. Similar to the main analysis, year, and industry dummies are added to the estimation models.

The estimation results show that the larger the MER_c, the larger the INTTRADE and INTFIN. This result is consistent with Hypothesis 1.

\subsubsection{System-GMM approach}

This section estimates the main models, Eqs (1)-(4), in a dynamic panel model with SystemGMM (Blundell \& Bond, 1998). The System-GMM can address the following problems: (1) the impact of firm fixed effects, (2) the dynamic impact of trading structures and production equipment, and (3) endogeneity.

For Eqs (1) and (2) regarding Hypothesis 1, the first-order lags of lnNI_s(lnNI_c) to the independent variables are added and the first-order lags of $\operatorname{lnNI} s(\operatorname{lnNI} c), \mathrm{L} \_s\left(\mathrm{~L} \_c\right)$, and $\mathrm{K} \_\mathrm{s}\left(\mathrm{K} \_\mathrm{c}\right)$ as are used endogenous variables while the other variables are added as instrumental variables. For Eqs (3) and (4) regarding Hypothesis 2, the first- and second-order lags of GS_s(GS_c) are added to Eqs (3) and (4) and are estimated as endogenous variables, while the other variables are added as instrumental variables. Note that industry dummies are excluded from the estimation equation because firm fixed effects are accounted for in the System-GMM.

The results estimated by System-GMM are consistent with Hypothesis 1 and Hypothesis 2 as well as with the results of the main analysis. ${ }^{2}$

\section{Conclusions}

This study focused on a Japanese corporate group with stakeholder-oriented corporate governance and examined PP conflicts between the parent company and non-controlling shareholders in subsidiaries. The findings of this study revealed that (1) the larger the noncontrolling interest ratio of the subsidiaries, the more profits are shifted to the parent company; (2) the larger the non-controlling interest ratio of the subsidiaries, the higher is the

\footnotetext{
2 System-GMM is estimated in both 1-step and 2-step, and similar results are obtained in both cases. Regarding the auxiliary tests, the $\operatorname{AR}(1)$ test is statistically rejected and the $\operatorname{AR}(2)$ test is not statistically rejected. However, the Sargan test is rejected, which may lead to bias in the estimation results using System-GMM.
} 
sales growth of the subsidiaries, not the parent company. Through additional tests, this study found that companies with lower foreign shareholdings, where the corporate governance of the parent company is considered to be closer to stakeholder-oriented, do not observe profit shifting to the parent company and have a stronger tendency to enable the entire corporate group to grow in terms of sales. These results suggest that even in Japanese companies with stakeholder-oriented corporate governance, the parent company exploits the wealth of noncontrolling shareholders and PP conflicts can be serious, but the parent company mitigates the influence of PP conflicts by allocating sales growth opportunities to its subsidiaries. This paper empirically demonstrates that stakeholder-oriented corporate governance can mitigate PP conflicts. Furthermore, this study suggests that the corporate governance orientation of the parent company, which is the controlling shareholder, is important in mitigating PP conflicts, not only in subsidiaries where PP conflicts occur. When considering PP conflicts, the corporate governance orientation of the parent company needs to be considered. In addition, this paper demonstrates that PP conflicts in subsidiaries influence the management style throughout the corporate group.

This study had a few limitations. One of them was the lack of analysis of the situation of each subsidiary. This is essential because profit shifting can occur not only between a parent company and its subsidiaries, but also between one subsidiary and other subsidiaries. Moreover, if the composition of non-controlling shareholders could be used in the analysis, it might be possible to identify the differences in the impact of various types of non-controlling shareholders on PP conflicts. Future studies should conduct more detailed analysis by obtaining the data of individual companies within a corporate group.

\section{Funding}

Akihiro Yamada was supported by the Grant-in-Aid for Young Scientists [MEXT/JSPS KAKENHI Grant Number 19K13862].

\section{Author contributions}

Fujita: conceptualization, validation, investigation, data curation, writing first draft, visualization; Yamada: conceptualization, methodology, formal analysis, resources, data curation, writing review \& editing, supervision, funding acquisition.

\section{Disclosure statement}

The authors of this paper declare that there are no competing financial, professional, or personal interests with other parties. 


\section{References}

Abegglen, J. C., \& Stalk, G. (1985). Kaisha, the Japanese corporation. Basic Books.

Accounting Standards Board of Japan. (2013). ASBJ Statement No. 22 accounting standard for consolidated financial statements. https://www.asb.or.jp/jp/wp-content/uploads/20200331_06.pdf

Aguilera, R. V., \& Jackson, G. (2003). The cross-national diversity of corporate governance: Dimensions and determinants. Academy of Management Review, 28(3), 447-465. https://doi.org/10.5465/amr.2003.10196772

Almeida, H. V., \& Wolfenzon, D. (2006). A theory of pyramidal ownership and family business groups. The Journal of Finance, 61(6), 2637-2680. https://doi.org/10.1111/j.1540-6261.2006.01001.x

Aoki, M. (1990). Toward an economic model of the Japanese firm. Journal of Economic Literature, 28(1), 1-27.

Bae, K.-H., Kang, J.-K., \& Kim, J.-M. (2002). Tunneling or value added? Evidence from mergers by Korean business groups. The Journal of Finance, 57(6), 2695-2740. https://doi.org/10.1111/1540-6261.00510

Bank of Japan. (1996-2012). Honpo Taigai Shisan Fusai Zandaka, Shoken Toshi Tou (Fusai) Zandaka Chiikibetsu Tokei [Japan's outstanding overseas assets and liabilities: Statistics on outstanding equity securities (liabilities) by region]. https://www.boj.or.jp/statistics/br/bop/index.htm/

Bauer, A. M., Fang, J., Pittman, J., Zhang, Y., \& Zhao, Y. (2020). How aggressive tax planning facilitates the diversion of corporate resources: Evidence from path analysis. Contemporary Accounting Research, 37(3), 1882-1913. https://doi.org/10.1111/1911-3846.12563

Bertrand, M., Mehta, P., \& Mullainathan, S. (2002). Ferreting out tunneling: An application to Indian business groups. The Quarterly Journal of Economics, 117(1), 121-148. https://doi.org/10.1162/003355302753399463

Blinder, A. (2000, December 5). More like them? The American Prospect. https://prospect.org/world/ like-them/

Blundell, R., \& Bond, S. (1998). Initial conditions and moment restrictions in dynamic panel data models. Journal of Econometrics, 87(1), 115-143. https://doi.org/10.1016/S0304-4076(98)00009-8

Chang, S. J., \& Hong, J. (2000). Economic performance of group-affiliated companies in Korea: Intragroup resource sharing and internal business transactions. The Academy of Management Journal, 43(3), 429-448. https://doi.org/10.5465/1556403

Charkham, J. P., \& Ploix, H. (2005). Keeping better company: Corporate governance ten years on. Oxford University Press. https://doi.org/10.1093/acprof:oso/9780199243198.001.0001

Claessens, S., Djankov, S., \& Lang, L. H. P. (2000). The separation of ownership and control in East Asian Corporations. Journal of Financial Economics, 58(1), 81-112. https://doi.org/10.1016/S0304-405X(00)00067-2

Clark, R. (1979). The Japanese company. Yale University Press.

Colpan, A. M., Yoshikawa, T., Hikino, T., \& Brio, E. B. D. (2011). Shareholder heterogeneity and conflicting goals: Strategic investments in the Japanese electronics industry. Journal of Management Studies, 48(3), 591-618. https://doi.org/10.1111/j.1467-6486.2010.00958.x

Cronqvist, H., \& Nilsson, M. (2003). Agency costs of controlling minority shareholders. Journal of Financial and Quantitative Analysis, 38(4), 695-719. https://doi.org/10.2307/4126740

Desender, K. A., Aguilera, R. V., Lópezpuertas-Lamy, M., \& Crespi, R. (2016). A clash of governance logics: Foreign ownership and board monitoring. Strategic Management Journal, 37(2), 349-369. https://doi.org/10.1002/smj.2344

Dharwadkar, B., George, G., \& Brandes, P. (2000). Privatization in emerging economies: An agency theory perspective. Academy of Management Review, 25(3), 650-669. https://doi.org/10.2307/259316 
Faccio, M., Lang, L. H. P., \& Young, L. (2001). Dividends and expropriation. American Economic Review, 91(1), 54-78. https://doi.org/10.1257/aer.91.1.54

Ferris, S. P., Kim, K. A., \& Kitsabunnarat, P. (2003). The costs (and benefits?) of diversified business groups: The case of Korean chaebols. Journal of Banking \& Finance, 27(2), 251-273. https://doi.org/10.1016/S0378-4266(01)00248-5

Financial Times. (2007a). TSE plans crackdown on groups that abuse minority investor rights: [Asia edition]. https://search.proquest.com/docview/250031117

Financial Times. (2007b). Subsidiaries in Japan THE LEX: [London $2^{\text {nd }}$ edition]. https://search.proquest.com/docview/250044187

Gomes, A. (2000). Going public without governance: Managerial reputation effects. The Journal of Finance, 55(2), 615-646. https://doi.org/10.1111/0022-1082.00221

Griliches, Z. (1988). Productivity puzzles and R\&D: Another nonexplanation. Journal of Economic Perspectives, 2(4), 9-21. https://doi.org/10.1257/jep.2.4.9

Hansmann, H., \& Kraakman, R. (2001). The end of history for corporate law. Georgetown Law Journal, 89, 439-468.

He, J., Mao, X., Rui, O. M., \& Zha, X. (2013). Business groups in China. Journal of Corporate Finance, 22, 166-192. https://doi.org/10.1016/j.jcorpfin.2013.05.001

Hines, J. R., \& Rice, E. M. (1994). Fiscal paradise: Foreign tax havens and American business. The Quarterly Journal of Economics, 109(1), 149-182. https://doi.org/10.2307/2118431

Huyghebaert, N., \& Wang, L. (2012). Expropriation of minority investors in Chinese listed firms: The role of internal and external corporate governance mechanisms. Corporate Governance: An International Review, 20(3), 308-332. https://doi.org/10.1111/j.1467-8683.2012.00909.x

Jebran, K., Chen, S., \& Tauni, M. Z. (2019). Principal-principal conflicts and corporate cash holdings: Evidence from China. Research in International Business and Finance, 49, 55-70. https://doi.org/10.1016/j.ribaf.2019.02.010

Jensen, M. C., \& Meckling, W. H. (1976). Theory of the firm: Managerial behavior, agency costs and ownership structure. Journal of Financial Economics, 3(4), 305-360. https://doi.org/10.1016/0304-405X(76)90026-X

Jiang, F., Cai, W., \& Zhu, B. (2018). Multiple large shareholders and corporate investment: Evidence from China. Journal of Corporate Finance, 50, 66-83. https://doi.org/10.1016/j.jcorpfin.2018.02.001

Jiang, G., Rao, P., \& Yue, H. (2015). Tunneling through Non-Operational Fund Occupancy: An investigation based on officially identified activities. Journal of Corporate Finance, 32, 295-311.

https://doi.org/10.1016/j.jcorpfin.2014.10.011

Judge, W., \& Zattoni, A. (2012). Introduction. In A. Zattoni \& W. Judge (Eds.), Corporate governance and initial public offerings: An international perspective (pp. 1-36). Cambridge University Press. https://doi.org/10.1017/CBO9781139061513.011

Kester, W. C. (1991). Japanese takeovers: The global contest for corporate control. Harvard Business School Press.

Khanna, T., \& Rivkin, J. W. (2001). Estimating the performance effects of business groups in emerging markets. Strategic Management Journal, 22(1), 45-74. https://doi.org/10.1002/1097-0266(200101)22:1<45::AID-SMJ147>3.0.CO;2-F

La Porta, R., Lopez-De-Silanes, F., \& Shleifer, A. (1999). Corporate ownership around the world. The Journal of Finance, 54(2), 471-517. https://doi.org/10.1111/0022-1082.00115

Lewellyn, K., \& Judge, W. (2012). Corporate governance and initial public offerings in the United States. In A. Zattoni, \& W. Judge (Eds.), Corporate governance and initial public offerings: An international perspective (pp. 520-547). Cambridge University Press.

https://doi.org/10.1017/CBO9781139061513.011 
Lincoln, J. R., \& Gerlach, M. L. (2004). Japan's network economy: Structure, persistence, and change. Cambridge University Press. https://doi.org/10.1017/CBO9780511584442

Lincoln, J. R., Gerlach, M. L., \& Takahashi, P. (1992). Keiretsu networks in the Japanese economy: A dyad analysis of intercorporate ties. American Sociological Review, 57(5), 561-585. https://doi.org/10.2307/2095913

Lins, K. V. (2003). Equity ownership and firm value in emerging markets. Journal of Financial and Quantitative Analysis, 38(1), 159-184. https://doi.org/10.2307/4126768

Morck, R., Wolfenzon, D., \& Yeung, B. (2005). Corporate governance, economic entrenchment, and growth. Journal of Economic Literature, 43(3), 655-720. https://doi.org/10.1257/002205105774431252

Opoku-Mensah, E., \& Yin, Y. (2021). Controlling shareholders' influence on acquisition decisions and value creation: An empirical study from China. International Journal of Finance and Economics, 1-16. https://doi.org/10.1002/ijfe.2520

Pan, Y. (1997). The formation of Japanese and U.S. equity joint ventures in China. Strategic Management Journal, 18(3), 247-254. https://doi.org/10.1002/(SICI)1097-0266(199703)18:3<247::AID-SMJ873>3.0.CO;2-O

Pan, Y., \& Li, X. (2000). Joint venture formation of very large multinational firms. Journal of International Business Studies, 31(1), 179-189. https://doi.org/10.1057/palgrave.jibs.8490896

Sakawa, H., \& Watanabel, N. (2012). Corporate governance and initial public offerings in Japan. In A. Zattoni \& W. Judge (Eds.), Corporate governance and initial public offerings: An international perspective (pp. 238-261). Cambridge University Press. https://doi.org/10.1017/CBO9781139061513.011

Sakawa, H., \& Watanabel, N. (2018). Parent control and ownership monitoring in publicly listed subsidiaries in Japan. Research in International Business and Finance, 45, 7-14. https://doi.org/10.1016/j.ribaf.2017.07.127

Sakawa, H., \& Watanabel, N. (2020). Institutional ownership and firm performance under stakeholderoriented corporate governance. Sustainability, 12(3), 1021. https://doi.org/10.3390/su12031021

Sakawa, H., \& Watanabel, N. (2021). Family control and corporate innovation in stakeholder-oriented corporate governance. Sustainability, 13(9), 5044. https://doi.org/10.3390/su13095044

Sauerwald, S., Heugens, P. P. M. A. R., Turturea, R., \& Essen, M. van. (2019). Are all private benefits of control ineffective? Principal-principal benefits, external governance quality, and firm performance. Journal of Management Studies, 56(4), 725-757. https://doi.org/10.1111/joms.12420

Shleifer, A., \& Vishny, R. W. (1997). A survey of corporate governance. The Journal of Finance, 52(2), 737-783. https://doi.org/10.1111/j.1540-6261.1997.tb04820.x

Yoshimori, M. (1995). Whose company is it? The concept of the corporation in Japan and the west. Long Range Planning, 28(4), 2-44. https://doi.org/10.1016/0024-6301(95)00025-E

Young, M. N., Peng, M. W., Ahlstrom, D., Bruton, G. D., \& Jiang, Y. (2008). Corporate governance in emerging economies: A review of the principal-principal perspective. Journal of Management Studies, 45(1), 196-220. https://doi.org/10.1111/j.1467-6486.2007.00752.x 


\section{APPENDIX}

\section{Variable definitions}

\begin{tabular}{|c|c|}
\hline Variables & Definition \\
\hline $\ln \mathrm{NI}$ & Natural logarithm of net income. \\
\hline GS & Growth rate of sales (Dsales divided by sales of previous term). \\
\hline MER & $\begin{array}{l}\text { Ratio of non-controlling interests to net assets in consolidated financial } \\
\text { statements. }\end{array}$ \\
\hline $\ln \mathrm{L}$ & Natural logarithm of the number of employees. \\
\hline $\ln K$ & Natural logarithm of property, plant, and equipment. \\
\hline $\operatorname{lnRDINT}$ & The natural logarithm of the ratio of $\mathrm{R} \& \mathrm{D}$ expenditures to net sales plus one. \\
\hline $\operatorname{lnLISTSUBR}$ & Natural logarithm of the ratio of listed subsidiaries to total subsidiaries. \\
\hline DHOLDINGS & $\begin{array}{l}\text { Dummy variable that is set to } 1 \text { if the ratio of affiliate securities to total } \\
\text { assets in the non-consolidated financial statements is } 50 \% \text { or more, and } 0 \\
\text { otherwise. }\end{array}$ \\
\hline TOP10 & $\begin{array}{l}\text { Ratio of the number of shares held by the top } 10 \text { shareholders of the parent } \\
\text { company to the total number of shares outstanding. }\end{array}$ \\
\hline EXEC & $\begin{array}{l}\text { Ratio of the number of shares held by executives of the parent company to } \\
\text { the total number of shares outstanding. }\end{array}$ \\
\hline FIN & $\begin{array}{l}\text { Ratio of the number of shares held by financial institutions of the parent } \\
\text { company to the total number of shares outstanding. }\end{array}$ \\
\hline FGN & $\begin{array}{l}\text { Ratio of the number of shares held by foreign shareholders of the parent } \\
\text { company to the total number of shares outstanding. }\end{array}$ \\
\hline BIG4 & $\begin{array}{l}\text { Dummy variable that is set to } 1 \text { if the Big } 4 \text { member-firms audit the } \\
\text { consolidated financial statements, and } 0 \text { otherwise. }\end{array}$ \\
\hline Q & $\begin{array}{l}\text { Total market value of shares at the end of the period and total liabilities } \\
\text { divided by net assets. }\end{array}$ \\
\hline SIZE & Natural logarithm of total assets. \\
\hline RISK & Standard deviation of annual stock returns over three periods. \\
\hline CAPITAL & Net assets divided by total assets. \\
\hline AGE & $\begin{array}{l}\text { Number of years elapsed from the year of establishment of the parent } \\
\text { company to the period } t \text {. }\end{array}$ \\
\hline
\end{tabular}

